\title{
Roadmap to Digital Marketing
}

\author{
Amisha Gupta ${ }^{1}$, Sunita Joshi ${ }^{2,}$ Harshit Gupta ${ }^{3}$ \\ ${ }^{1} \mathrm{UG}$ - Bachelors of Science-Information Technology, MRIIRS, Faridabad, Haryana \\ ${ }^{2}$ Assistant Professor, Computer Applications, MRIIRS, Faridabad, Haryana \\ ${ }^{3}$ UG-Bachelors of Technology-Information Technology, BPIT, Rohini, Delhi
}

\begin{abstract}
For hundreds of years, self-business is a critical term that consistently comes to market, particularly for helpless families who set up small-scale businesses to earn the necessities. But with the advancement of technology and a step towards the digital world, we shifted from manual work to digital form.[1] To counter this manual work, marketers decided to use the most powerful platform that is DIGITAL MARKETING. It is a component of marketing that utilizes the Internet and digital technologies like smartphones, laptops to reach consumers at a significant level, promote their products to them, and earn great profit. [12]This paper mainly studies digital marketing, including the difference and contact between digital and traditional marketing, digital marketing over traditional marketing, solutions to digital marketing, the role of social media as a promoter of it, and its future scope.[2] As per the research, every country has oriented to UPI payment, Aadhar connects payment,[10] android/iOS applications, and many more.[1] These solutions help us to build a secure platform for any transaction and help our business to grow. Social media is one of the best platforms to support digital marketing as it furnishes individuals with the chance to communicate and share posts and points.[3] If this approach of digital marketing has taken to all parts of the world, then the result will be very fruitful.[9]
\end{abstract}

Keywords: Digital Marketing, Traditional Vs. Digital Marketing, Digital Market Over Traditional Market, Solutions for Digital Market, Role of social media As Promoter, Future Scope.

\section{INTRODUCTION}

With the coming of the Internet age, some old marketing techniques have been disposed of and supplanted with new strategies for product selling and showcasing. "DESK WORK" has transformed into "DIGITAL WORK AND ONLINE EXPLORATION." [4] The uprising that has occurred in the field of IT has changed the method of marketing. This recent method is a lot less expensive, more straightforward, valuable, and demonstrated to be fruitful.[9] Without really entering the market/shop, neither sitting around idly nor wasting cost nor energy, one can discover what needs and make purchases with a quick click [14]

\subsection{Traditional Marketing}

\section{TRADITIONAL MARKETING VS DIGITAL MARKETING}

Traditional marketing is the most acknowledged type of advertising that has been fruitful for quite a long time. It includes numerous recognizable types of promoting that we watch and tune into our regular day-to-day existence.[2] Techniques for traditional marketing can consist -

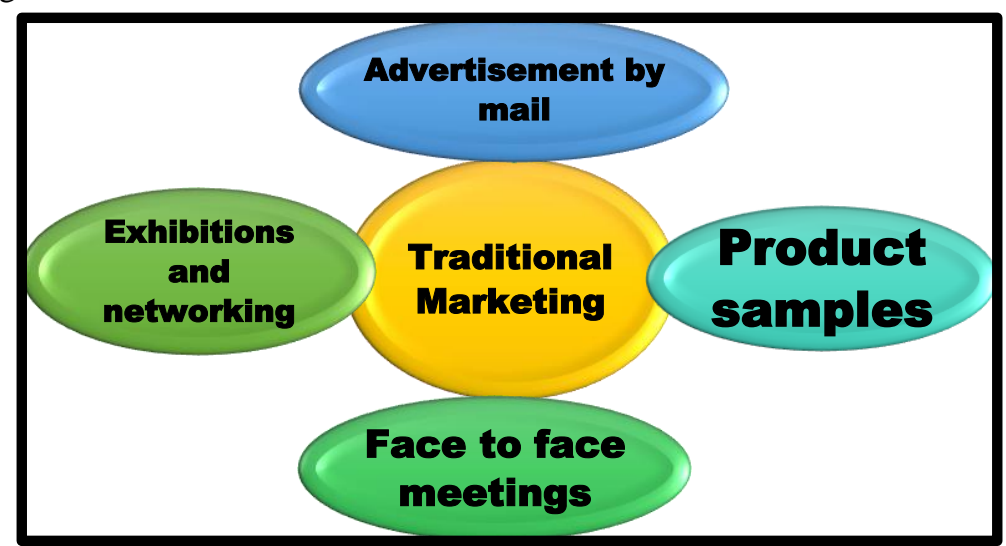

Figure 1. Traditional Marketing Techniques

- $\quad$ Printing marketing- is one of the old strategies for customary showcasing, which has been expected since former times. It is the procedure of publicizing in paper structure through papers, magazines, and bulletins circulated to the clients. [refer to figure1] 


\section{International Advanced Research Journal in Science, Engineering and Technology}

Vol. 8, Issue 6, June 2021

\section{DOI: $10.17148 / I A R J S E T .2021 .8677$}

- $\quad$ Advertisements by mail- Regular postal mail Marketing utilizes printed material like postcards, handouts, letters, inventories, and flyers sent through postal mail to the clients.

\subsection{Digital Marketing}

The advancement of products and services using the digital network to reach customers across the globe is known as digital marketing.[2] Techniques for digital marketing include-

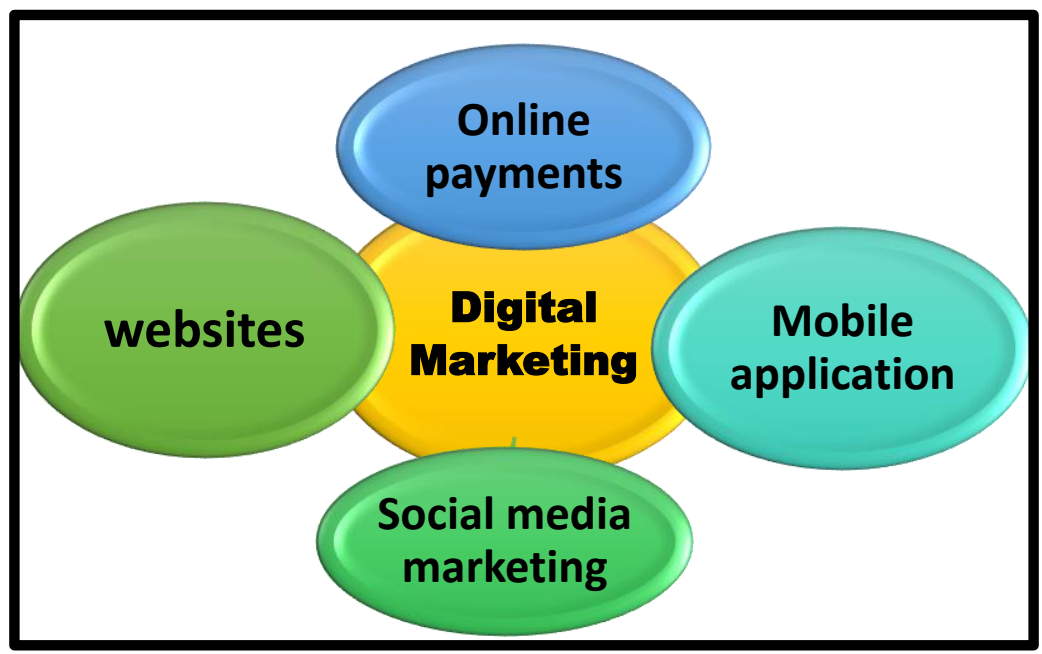

Figure 2. Digital Marketing Techniques

- Websites- For some organizations, sites have replaced organization stores or print distributions. For B2B organizations, they've supplanted the corporate handout and can assume a significant part in Supporting your image and working with sales.[11]

- Online payments- The utilization of e-payments balances drafting checks, sending money and invoice for the two organizations and clients. That allows quicker execution of transactions. [refer to figure 2]

\section{- Cost}

\section{WHY DIGITAL MARKETING HAS OVERCOME TRADITIONAL MARKETING}

Traditional marketing strategies are more costly than digital marketing techniques because traditional promoting advertisements about the product require an enormous cost to concentrate on a more significant mass gathering. In contrast, digital marketing has numerous types of advanced promoting methods that are free of charge.[2]

\section{- Hard to target audience}

Digital marketing is not difficult to determine who visited our website, how often they visit, and what they view. Still, on the other hand, in traditional marketing, once a print media mailed or delivered, it becomes much difficult to predict who read it and who view our advertisement.[2]

\section{Less information}

The information delivered by traditional techniques is much precise and less. Still, through digital strategies, in websites, we can open multiple banners and links, and there is limitless freedom to share as much information as possible.[2]

\section{- Time constraints}

Traditional marketing doesn't permit one to react to changes in the commercial center as fast as computerized methods of communication. As making magazine promotions and day by day paper advertisements may need a week or month advance. Likewise, changing transmission advertisements requires time and extra creation costs. Then again, on the Internet, one can, in a flash, refresh the website pages or Facebook pages to tell clients about the item or administration.[15]

\section{SOLUTIONS FOR DIGITAL MARKETING}

Here are some solutions to digital marketing that will help marketers maximize their profit and help them grow their business.

\section{- Digital analytics-}

It is a process of gathering digital data from various sources like websites, social media, and mobile applications [8] and helps us improve our marketing strategies to earn significant profits.[5] 


\section{International Advanced Research Journal in Science, Engineering and Technology}

Vol. 8, Issue 6, June 2021

\section{DOI: $10.17148 / I A R J S E T .2021 .8677$}

\section{- Online payments-}

UPI payments and Aadhar connect payments will give us a secure platform to do money transactions. Thus, online payments will make marketing much easier and faster.[7]

\section{- Android application-}

It is the fastest way for humans to buy any product anytime and from anywhere. It is the best solution that we face time constraints in traditional marketing.[1]

\section{- Email advertising-}

Our exceptional email marketing arrangement works backward. Rather than your designated client going to your site, you approach them and make a retargeting mailing list.

\section{ROLE OF SOCIAL MEDIA AS A PROMOTER}

The imperfection in traditional marketing is that it hits each area of society, not the one specific designated area. To counter this defect, marketers chose to utilize the grandest stage of this era: social media. SOCIAL MEDIA MARKETING is vital for marking items or administrations as it relies upon Hash-Tags for the relationship with the customer.[3] Marketers would utilize the hash-tag for profile examination to such an extent that they have arranged into different classes. After the outcome is created, it would assist marketers in targeting a specific set of people. Likewise, it would help superior lead generation, increment the number of sales and develop an incredible business connection within the community.[6] Some best social media sites are Facebook, Instagram, and Google+.

\section{FUTURE SCOPE}

With the implementation of this idea and making full use of new and upcoming technologies, we can establish a new way for marketing.[13] We can get many benefits from it. Digital Marketing scope in the future of marketing will flourish the most result-oriented trend and let businesses survive and allow them to grow.[1] Digital marketing has many aspects that include copy, design, technology, and social media, marketing, finance, and business development. Therefore, the growth of digital marketing will also lead to change in all these aspects. That will increase the number of jobs available for these sub-sectors, and students can make solid and long-lasting careers in this last digital marketing are the future and the most productive way for the betterment of the world.

\section{REFERENCES}

[1]. Kalra, Ramneek Kumar, Kamal Batra, Shivani Namrata," Smart market: A step towards digital India', 2017 International Conference on Computing and Communication Technologies for Smart Nation, IC3TSN 2017

[2]. Ms. Sudha Lawrence, Ms. Snehal Deshmukh, Ms. Elavarasi Navajivan," A Comparative Study of Digital Marketing Vs Traditional Marketing", IIBM's Journal of Management Research,2018

[3]. Bhor, Harsh Namdev Koul, Tushar Malviya, Rajat Mundra, Karan," Digital media marketing using trend analysis on social media", Proceedings of the 2nd International Conference on Inventive Systems and Control, ICISC 2018

[4]. Hsiao, Tsung Chih Han, Carol Qi, Mixue Yu, Xiaoguang," The development and research of digital marketing in the contemporary society", 2016 International Conference on Applied System Innovation, IEEE ICASI 2016

[5]. Henning Xu, Gary L. Frankwick, Edward Ramirez," Effects of big data analytics and traditional marketing analytics on new product success: A knowledge fusion perspective", Journal of Business Research,2016

[6]. Priyanka Kumari. "A Study of Customer Preference and Attitude towards Online Shopping In Bihar". International Research Journal on Advanced Science Hub, 3, Special Issue ICEST 1S, 2021, 7-11. doi: 10.47392/irjash.2021.012

[7]. Srinivasan, Dr Shaik Naseera," A Comprehensive Review: Trust and Location Based Security Mobile Social Networks", International Journal for Research in Engineering Application \& Management (IJREAM) ISSN: 2454-9150 Vol-03, Issue-05, Aug 2017

[8]. Balakrishnan, Mahadevan. "Indian payment systems and financial inclusion: Current status and next steps." Journal of Payments Strategy \& Systems 9.3 (2015): 242-293

[9]. Ahmad A . I . Shajrawi; Nawab Ali Khan. "International Marketing in the Modern Era". International Research Journal on Advanced Science $H u b, 2$, Special Issue ICAET 11S, 2020, 16-19. doi: 10.47392/irjash.2020.227

[10]. J. Hurwitz, M. Kaufman, A. Bowles, A. Nugent, J. G. Kobielus, and M. D. Kowolenko, Cognitive Computing and Big Data Analytics. Hoboken, NJ, USA: Wiley, 2015.

[11]. D. RyanC. Jones, "Understanding Digital Marketing: Marketing Strategies for Engaging the Digital Generation," Journal of Direct Data \& Digital Marketing Practices, Vol10(4). pp.384-387,2009

[12]. Bhatti, Bharat. "Aadhaar-enabled payments for NREGA workers." Economic \& Political Weekly 47.49 (2012): 16-19.

[13]. J. Jarvinen, A. Tollinen, H. Karjaluoto and C. Jayawardhena," Digital and social media marketing usage in b2b industrial section, "Marketing Management Journal, Vol. 22, pp.102-117,2012.

[14]. L. Pacheco, "Marketing, reception and cinematographic critique in the digital era," Estudos Em Comunicao, pp. 351-365,2012.

[15]. Miklosik, Andrej, Evans, Nina," Impact of Big Data and Machine Learning on Digital Transformation in Marketing: A Literature Review", IEEE Access, 2020

[16]. Salini Suresh; Suneetha V; Niharika Sinha; Sabyasachi Prusty; Sriranga H.A. "Machine Learning: An Intuitive Approach In Healthcare". International Research Journal on Advanced Science Hub, 2, 7, 2020, 67-74. doi: 10.47392/irjash.2020.67

[17]. Rahimi, Farrokh, and Ali Ipakchi. "Demand response as a market resource under the smart grid paradigm." IEEE Transactions on Smart Grid 1.1 (2010): 82-88

[18]. Digital marketing over traditional marketing: https://bizfluent.com/info-7743048-disadvantages-traditional-marketing.html 